\title{
Restoration Measures Supported Surface Soil Carbon and Nitrogen Density in Alpine Grassland of Sanjiangyuan Region, China
}

\author{
Dongdong Chen ${ }^{1 \#}$, Qi Li ${ }^{1 \#}$, Fuquan $\mathrm{He}^{1}$, Xin Chen ${ }^{1,4}$, Shixiao Xu', Xinquan Zhao ${ }^{1 *}$, \\ Jingmei Li $^{2}$, Lihua Liu ${ }^{3}$, Liang Zhao ${ }^{1 * *}$
}

${ }^{1}$ Key Laboratory of Adaptation and Evolution of Plateau Biota, Northwest Institute of Plateau Biology, Chinese Academy of Science, Xining, Qinghai, China

${ }^{2}$ Qinghai Academy of Social Sciences, Xining, Qinghai, China

${ }^{3}$ Qinghai Engineering Consulting Center, Xining, Qinghai, China ${ }^{4}$ Graduate University of Chinese Academy of Sciences, Beijing, China

Received: 9 October 2019

Accepted: 19 November 2019

\begin{abstract}
Soil carbon $(\mathrm{C})$ and nitrogen $(\mathrm{N})$ have different responses to different restoration measures. In this paper, surface $(0-30 \mathrm{~cm})$ soil $\mathrm{C}$ and $\mathrm{N}$ densities under different restoration measures in the Sanjiangyuan region were investigated and analyzed. The results showed that although there was no significant difference between rest-grazing (RG) and normal grazing (NG) grassland, SOCD in RG increased by $10.15 \%$, and total $\mathrm{N}$ density (TND) increased by $8.56 \%$ in the year of the experiment. Compared with cropland, 8 years after Grain for Green (GFG), SOCD increased by 10.49-19.31\%, SICD increased by $22.47-54.20 \%$, and TND increased by $1.3-17.45 \%$. Compared with HTT (extreme degradation-black soil beach), 12 years after planting artificial grassland, SOCD increased by 43.97-77.21\%, SICD increased by 89.19-716.22\%, and TND increased by $49.16-71.40 \%$. Conclusions: Differences in soil types and climatic zones were responsible for the differences in soil $\mathrm{C}$ and $\mathrm{N}$ in different regions. Short-term grazing rest in Sanjiangyuan region has a certain effect on soil fertility restoration. Implementing the GFG project in the agro-pastoral ecotone improved soil fertility and, concurrently, moderate disturbance should be carried out on the basis of increasing vegetation diversity. Artificial grassland planting on black soil beach can improve soil quality, and moderate grazing disturbance in winter had the best immobilization effect on SIC, while no disturbance in the whole year was beneficial to the accumulation of organic matter. Both biological and abiotic factors have affected soil $\mathrm{C}$ and $\mathrm{N}$ content and density, but the degree of the influence varied with geographic location.
\end{abstract}

\footnotetext{
\# Authors who contributed equally to this work.

*e-mail: xqzhao@nwipb.cas.cn

**e-mail: 1zhao@nwipb.cas.cn
} 
Keywords: Qinghai-Tibetan Plateau, rest-grazing, grain for green, returning grazing land to grassland, soil carbon and nitrogen

\section{Introduction}

Located in the southern part of Qinghai Province and the hinterland of the Qinghai-Tibetan Plateau (QTP), Sanjiangyuan is the birthplace of the Yangtze River, the Yellow River and the Lancang River. It is known as the "Chinese Water Tower" and is also a region with high biodiversity and sensitive ecological environment [1]. In recent years, due to the impact of climate change and human activities, the ecosystem of Sanjiangyuan has been deteriorating, which has an important impact on the QTP. In order to protect the fragile ecoclimatic environment of Sanjiangyuan, effectively curb grassland degradation and maintain species diversity [2], the State Council launched the "General Plan for Ecological Protection and Construction of Sanjiangyuan Nature Reserve in Qinghai Province" in 2005, and implemented a series of ecological protection and construction projects such as Grain for Green (GFG), which transforms the cultivated land into natural vegetation or perennial artificial grassland/woodland. The aim is to protect and restore the ecological function, improve the regional ecological environment and promote the harmonious development of humans and nature [3]. At the same time, in order to protect the grassland ecological environment, the CPC Central Committee and the State Council proposed in 2011 to further improve the project of "returning grazing land to grassland". According to local conditions and technology, we should focus on rotational grazing and seasonal grazing rest, i.e., forbidding grazing policy for severely degraded grasslands or ecologically fragile areas with slow vegetation restoration, and grazing rest policy for areas with degradation, desertification and overgrazing but good grassland environment and vegetation condition [1, 4]. According to the actual situation in different areas, the local government has taken different measures to restore grassland. For example, in the agro-pastoral ecotone (like Tongde County), the long-term cultivated land is converted to forest and/or grassland. The measures of planting artificial grassland in pastoral areas (such as Maqin County) were adopted [1]. In order to prevent grassland deterioration and restore grassland ecology, the grazingrest policy should be implemented in areas with better grassland environment and vegetation conditions (Guinan County) [4].

Soil carbon (C) and nitrogen (N) are important components of soil nutrients, they are major nutrient sources for plant growth, and also play an important role in global $\mathrm{C}$ and $\mathrm{N}$ cycle and balance [5-6]. There are many studies on soil $\mathrm{C}$ and $\mathrm{N}$, mainly involving the effects of land use [7-9], management measures [10-12], restoration measures [13-19] on soil C and $\mathrm{N}$, and the relationship between plant functional groups and soil factors [20-22]. However, most related research in China has been concentrated in the Loess Plateau area $[10,13-14,17,19,22]$, but few studies have focused on alpine regions - especially the Sanjiangyuan region $[12,18,23-25]$. Based on the above grassland restoration background, we investigated the changes of $\mathrm{C}$ and $\mathrm{N}$ in grassland soil under different restoration measures in the Sanjiangyuan region. The purpose of this study is to clarify: 1) the level of soil $\mathrm{C}$ and $\mathrm{N}$ in different research areas and 2) the response degree of soil $\mathrm{C}$ and $\mathrm{N}$ to different restoration measures, and which measures lead to faster recovery of soil $\mathrm{C}$ and $\mathrm{N}$.

\section{Materials and Methods}

\section{Description of the Study Sites and Experiments}

\section{Rest-Grazing and Grazing Experiment}

Guinan County $\left(35^{\circ} 09^{\prime}-36^{\circ} 08^{\prime} \mathrm{N}, 100^{\circ} 13^{\prime}-101^{\circ} 33^{\prime} \mathrm{E}\right)$, Hainan Prefecture, Qinghai Province, is located in the northeastern edge of the QTP, with an average elevation of $3100 \mathrm{~m}$. The area is a typical plateau continental climate with an average annual temperature of $2.4^{\circ} \mathrm{C}$, precipitation of $415.8 \mathrm{~mm}$, evaporation of $1378.5 \mathrm{~mm}$ and 2712.7 sunshine hours [26-27]. The experimental site is located in Taxiu Township and Sendo Town, with an average elevation of about $3300 \mathrm{~m}$. The interval between the two sampling sites is about $20 \mathrm{~km}$. Half of the grasslands selected at each sampling site are rest-grazing (RG) during the green-returning period (which starts at the end of April 2016), and half are grazed normally (NG). The grassland environment and vegetation conditions in the experimental area were good. The main species were Kobresia humilis, Stipa capillata L., Festuca ovina, Medicago archiducis-nicolai, Astragalus propinquus Schischkin and Saussurea hieracioides Hook. F., Taraxacum mongolicum Hand.- Mazz. Soil samples were taken in mid-October 2016.

\section{'Grain for Green'Measures}

The experiment was carried out on Tongde Ranch $\left(34^{\circ} 09^{\prime} \mathrm{N}, 100^{\circ} 09^{\prime} \mathrm{E}\right)$ located in the Batan area, northeastern Tongde County, Qinghai Province, with an elevation of $3200 \mathrm{~m}$. The climate is typical plateau continental climate, with an average annual temperature of $0.2^{\circ} \mathrm{C}$, annual precipitation of $429.8 \mathrm{~mm}$, annual evaporation of $1466.4 \mathrm{~mm}$, and an annual sunshine duration of $2745.8 \mathrm{~h}$. The soil is dark chestnut calcareous soil [28].

Since 2002, according to local conditions, Tongde County began to implement large-scale measures of 
returning farmland to forest and grass. In forest belts, Caragana korshinskii Kom is mainly planted; Elymus breviaristatus (Keng) Keng $\mathrm{f}$. is planted in grass belts [29]. Grass seeds are harvested at the end of August every year, and straw is used for feeding cattle and sheep. Throughout the winter, cattle and sheep are allowed to feed in grass and forest belts. Grass belts are renewed/plowed every four years. The cultivated land in this area has a history of more than 60 years, mainly for rape (Brassica napus) and barley (Hordeum vulgare Linn. var. nudum Hook. f.) rotation. The main species in natural grazing grassland are Kobresia humilis, Stipa capillata L., Poa pratensis L., Oxytropis kansuensis Bunge, and Artemisia gmelinii Weber ex Stechmann, etc.

The land conversion began in 2008. And in this study, five treatments were chosen: cultivated land (cropland), grass belt (GRG1), forest belt (GFG2), enclosure (GRG3, a $25 \times 25 \mathrm{~m}$ fence for setting up flux equipment in the experimental area, which was built in 2008 without grazing interference), and natural grassland (NG, normal grazing was carried on). By October 2016 the sampling area had been restored for 8 years.

\section{Measures of Planting Artificial Grassland}

The experimental site is located in Maqin County, Guoluo Tibetan Autonomous Prefecture, Qinghai Province $\left(33^{\circ} 43^{\prime}-35^{\circ} 16^{\prime} \mathrm{N}, 98^{\circ} 48^{\prime}-100^{\circ} 56^{\prime} \mathrm{E}\right)$. The area has a continental cold and humid climate, with an average altitude of over $4100 \mathrm{~m}$, an annual average temperature of $-3.8-3.5^{\circ} \mathrm{C}$, and a large temperature difference between day and night. Annual precipitation ranges from $423 \mathrm{~mm}$ to $565 \mathrm{~mm}$, mostly in JuneSeptember. The annual sunshine time is $2313-2607 \mathrm{~h}$, with strong light radiation. Vegetation types are rich, mainly alpine meadows, which are the main natural grasslands for grazing. Soil types are mainly alpine meadow soil [30].

In this area, artificial grassland planting measures were implemented for the degraded grassland of "Black Soil Beach". Elymus nutans (upper grass) and Poa pratensis (lower grass) were mainly planted. The sampling area was established in 2002, and the pasture was fenced in the growing season, and the vegetation on the ground was used for winter grazing after seeds were collected. At the same time, a small fence of $25 \times 25 \mathrm{~m}$ was built in the experimental area, and the fence was for setting up flux equipment. There was no interference in the fence all year except for data collection. The sampling time was October 2014. The selected treatments were degenerated grassland (HTT), winter grazing pasture (WL), year-round forbidden grazing pasture (WF), and natural grazing (NG, normal grazing, the main species were Kobresia pygmaea, Kobresia humilis, Kobresia capillifolia, Stipa capillata L., Festuca ovina, Leontopodium leontopodioides, etc).

\section{Sample Collection and Processing}

In each sampling site, 4-6 sampling plots (about $10 \mathrm{~m} \times 5 \mathrm{~m}$ ) were set up, and the interval between the sites was more than $50 \mathrm{~m}$. According to the "S" sampling method, soil samples were collected by drilling layers (0-10, 10-20, 20-30) with a diameter of $3 \mathrm{~cm}$, and a mixed sample was formed by 5-6 drills per layer in each plot. Meanwhile, the soil bulk density was collected by a $3.8 \mathrm{~cm}$ ring knife.

After the soil samples were brought back to the laboratory, impurities were removed and part of them was used to determine soil water content. According to the quartile method, some soil samples were preserved at $4^{\circ} \mathrm{C}$ for the determination of inorganic nitrogen (SIN) and microbial biomass $\mathrm{C}$ and $\mathrm{N}$, while the others were air-dried and divided into two parts - one for determining soil $\mathrm{pH}$ and the other for determining SOC, $\mathrm{TN}$ and SIC after $0.15 \mathrm{~mm}$ screening.

\section{Soil C and N Analysis}

The bulk density and water content were determined by drying method, soil $\mathrm{pH}$ was determined in 1:2.5 (w/v) soil/ $\mathrm{KCl}$ extracts using a combination glass electrode, SIN was determined in $2 \mathrm{M} \mathrm{KCl}$ extracts with a Skalar San++ continuous flow analyzer (Skalar Analytical, Breda, The Netherlands), TN by Kjeldahl $\mathrm{N}$ analyzer, SOC by potassium dichromate-concentrated sulfuric acid oxidation, SIC by acid titration, and microbial biomass by chloroform fumigation and extraction [31].

Calculating $\mathrm{C}$ and $\mathrm{N}$ density [32]:

$$
\begin{aligned}
& \text { SOCD }=\sum_{\substack{\mathrm{i}=1 \\
\mathrm{n}}}^{\mathrm{n}} \mathrm{Di} \times \mathrm{BDi} \times \mathrm{SOCi}
\end{aligned}
$$

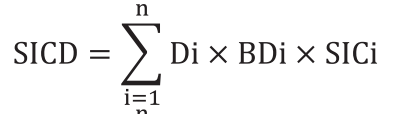

$$
\begin{aligned}
& \text { STND }=\sum_{i=1}^{n} \text { Di } \times \text { BDi } \times \text { STNi } \\
& \mathrm{TCD}=\mathrm{SOCD}+\mathrm{SICD}
\end{aligned}
$$

Among them, $\mathrm{n}$ is the soil layer, $\mathrm{i}$ is $0-10 \mathrm{~cm}$, $10-20 \mathrm{~cm}$ or $20-30 \mathrm{~cm}$. Di denotes the depth of the soil layer $(\mathrm{cm}), B D i$ denotes the bulk density of the layer $\left(\mathrm{g} \mathrm{cm}^{-3}\right), S O C i$, SICi and STNi denote the contents of SOC, SIC and STN $\left(\mathrm{g} \mathrm{kg}^{-1}\right)$ of each layer, respectively.

\section{Data Processing}

All statistical analyses were performed by SPSS ver. 16.0 for Windows (SPSS Inc., Chicago, IL, USA). Significant differences of measurement variables between different land use types were detected by one-way ANOVA or t-test $(P<0.05)$. When the variance is uniform, the minimum standard deviation (LSD) is used for multiple comparisons. When variance is inconsistent, the games-Howell test is used for 
post-test. Stepwise regression analysis was used to screen the main influencing factors of soil $\mathrm{C}$ and $\mathrm{N}$ change. The critical value of partial regression square sum of significance test was 0.05 .

\section{Results}

\section{Response of C and N Density to Rest-Grazing}

The average SOCD of $0-30 \mathrm{~cm}$ soil layer in the study area was $9.103(8.292-9.914) \mathrm{kg} \mathrm{m}^{-2}$, SICD was $1.338(1.162-1.514) \quad \mathrm{kg} \mathrm{m}^{-2}$, TND was 1.014 (0.940-1.088) $\mathrm{kg} \mathrm{m}^{-2}$ and TCD was 10.442 (9.806-11.077) $\mathrm{kg} \mathrm{m}^{-2}$ (Fig. 1, Table 2).

Changes of $\mathrm{C}$ and $\mathrm{N}$ densities in $0-30 \mathrm{~cm}$ soil layer: although there was no significant difference in $\mathrm{C}$ and $\mathrm{N}$ densities between the two treatments, SOCD, TND, TCD and SICD in RG increased by $10.15 \%, 8.56 \%$, $4.88 \%$ and $21.43 \%$, respectively, compared with the general grazing land.

\section{Response of C and N Density to 'Grain for Green'}

The average SOCD of $0-30 \mathrm{~cm}$ soil layer was $7.375(6.539-7.785) \mathrm{kg} \mathrm{m}^{-2}$, SICD was 3.561 (2.430$5.022) \mathrm{kg} \mathrm{m}^{-2}$, TND was $0.786(0.745-0.875) \mathrm{kg} \mathrm{m}^{-2}$ and
TCD was 10.93 (8.970-12.807) $\mathrm{kg} \mathrm{m}^{-2}$ (Fig. 2, Table 3).

SOCD in $0-30 \mathrm{~cm}$ soil layer: Compared with cultivated land, after 8 years of restoration, GFG1 increased by $10.49 \%$, GFG 2 increased by $15.09 \%$, and GFG3 increased by $19.31 \%$.

SICD in 0-30 cm soil layer: Compared with cultivated land, after 8 years of restoration, GFG1 increased by $49.42 \%$, GFG 2 increased by $54.20 \%$, and GFG3 increased by $22.47 \%$.

TND in 0-30 cm soil layer: Compared with cultivated land, after 8 years of restoration, GFG1 increased by $1.3 \%$, GFG 2 increased by $17.45 \%$, and GFG3 increased by $8.32 \%$.

TCD (SOCD+SICD) in 0-30 cm soil layer: Compared with cultivated land, after 8 years of restoration, GFG1 increased by $21.03 \%$, GFG 2 increased by $25.67 \%$, and GFG3 increased by $20.14 \%$.

Response of C and $\mathrm{N}$ Density to the Establishment of Artificial Grassland

The average SOCD in $0-30 \mathrm{~cm}$ soil layer was $10.896(6.491-16.246) \mathrm{kg} \mathrm{m}^{-2}$, SICD was $0.135(0.037-$ $0.302) \mathrm{kg} \mathrm{m}^{-2}$, TND was $1.005(0.598-1.504) \mathrm{kg} \mathrm{m}^{-2}$ and TCD was $11.032(6.528-16.378) \mathrm{kg} \mathrm{m}^{-2}$ (Fig. 3, Table 4).

SOCD in $0-30 \mathrm{~cm}$ soil layer: Compared with HTT, after 12 years of recovery, WL increased by $43.97 \%$ and WF increased by $77.21 \%$. a)

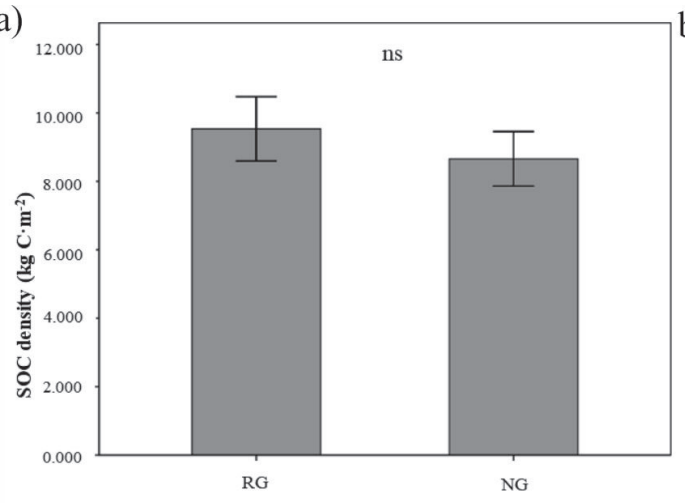

c)

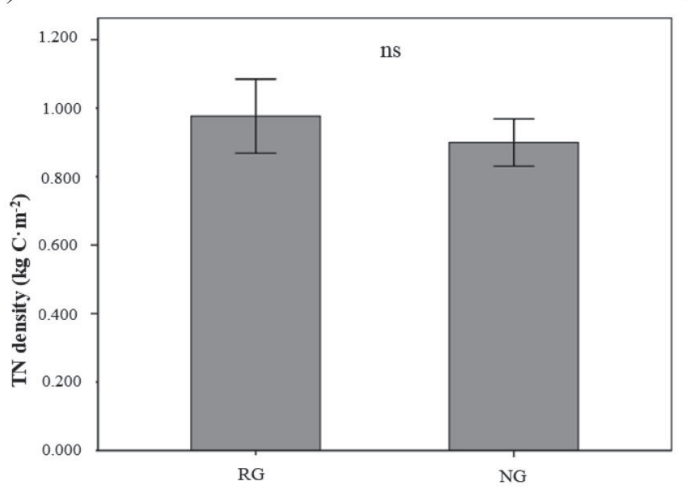

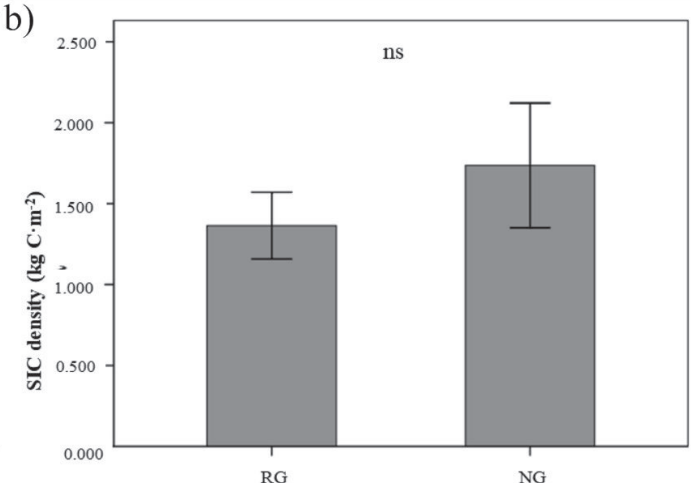

d)

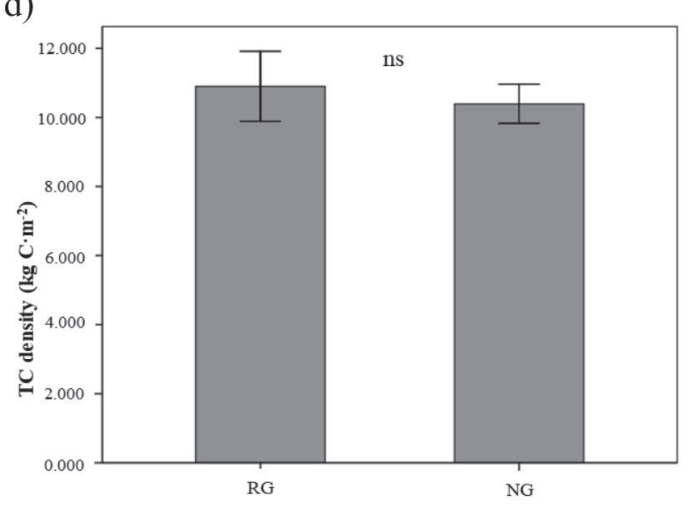

Fig. 1. Soil organic carbon density (SOCD, a), soil inorganic carbon density (SICD, b), total nitrogen density (TND, c) and total carbon density $(\mathrm{TCD}, \mathrm{d})$ in surface $(0-30 \mathrm{~cm})$ soil of RG (rest-grazing in returning green period) and $\mathrm{NG}$ (normal grazing grassland). There were no significant differences between $\mathrm{RG}$ and $\mathrm{NG}$ at $P<0.05$ for all the indicators. Bars indicate mean $\pm \mathrm{SD}$ (standard deviation). 

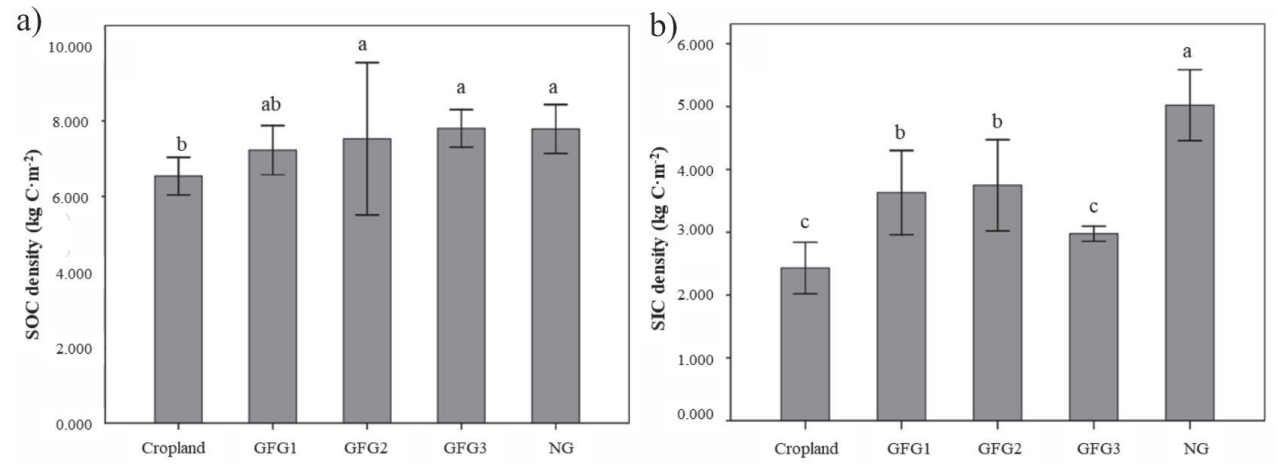

c)

d)
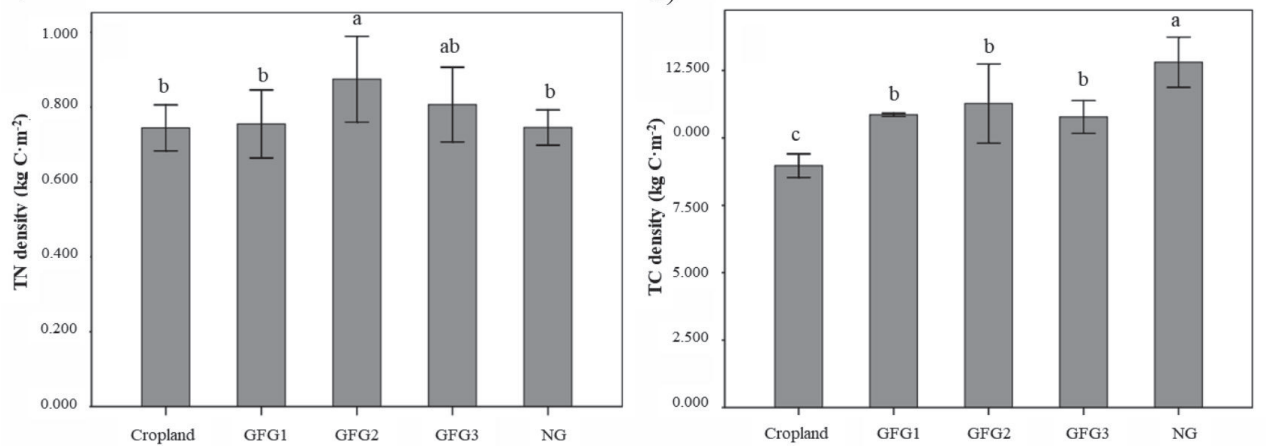

Fig. 2. Soil organic carbon density (SOCD, a), soil inorganic carbon density (SICD, b), total nitrogen density (TND, c) and total carbon density (TCD, d) in surface $(0-30 \mathrm{~cm}$ ) soil of cropland, GFG1 (grass belt), GFG2 (forest belt), GFG3 (enclosure) and NG (normal grazing grassland). Different lowercase letters indicate significant differences between different treatments at $P<0.05$. Bars indicate mean $\pm \mathrm{SD}$.
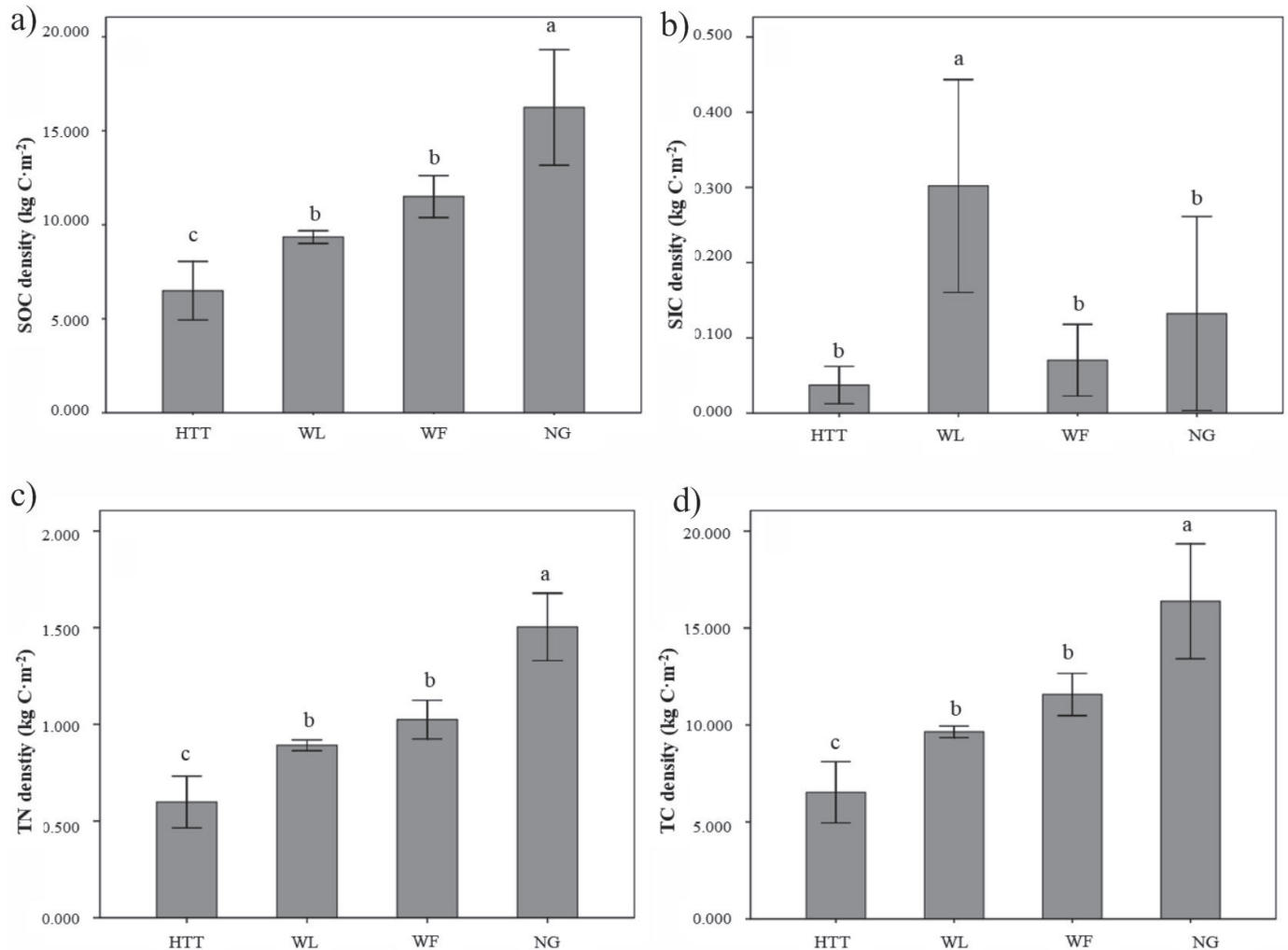

Fig. 3. Soil organic carbon density (SOCD, a), soil inorganic carbon density (SICD, b), total nitrogen density (TND, c) and total carbon density $(\mathrm{TCD}, \mathrm{d})$ in surface $(0-30 \mathrm{~cm})$ soil of HTT (extreme degradation-black soil beach), WL (winter grazing pasture), WF (year-round forbidden grazing pasture) and NG (normal grazing grassland). Different lowercase letters indicate significant differences between different treatments at $P<0.05$. Bars indicate mean $\pm \mathrm{SD}$. 
Table 1. Regression models relating soil $\mathrm{C}$ and $\mathrm{N}$ with soil properties and belowground biomass with soil depth under all and different treatments.

\begin{tabular}{|c|c|c|c|}
\hline Sites & Treatment & Linear Models & $\mathrm{R}^{2}$ \\
\hline \multirow{18}{*}{$\begin{array}{l}\text { Tongde } \\
\text { County }\end{array}$} & \multirow{3}{*}{ Total } & $\mathrm{SOC}=7.472+0.012 \mathrm{MBC}+4.459 \mathrm{TN}$ & $0.847 * * *$ \\
\hline & & $\mathrm{TN}=1.014+0.066 \mathrm{SOC}+0.532 \mathrm{WACD}-0.024 \mathrm{SM}-0.021 \mathrm{SIC}$ & $0.848 * * *$ \\
\hline & & $\mathrm{SIC}=-90.361+13.594 \mathrm{pH}-8.815 \mathrm{AWCD}+0.007 \mathrm{MBC}$ & $0.581 * * *$ \\
\hline & \multirow{3}{*}{ Cropland } & $\mathrm{SOC}=2.893+7.482 \mathrm{TN}$ & $0.997 * * *$ \\
\hline & & $\mathrm{TN}=0.881+0.068 \mathrm{SOC}$ & $0.863 * * *$ \\
\hline & & $\mathrm{SIC}=-182.579+24.796 \mathrm{pH}$ & $0.998^{* * *}$ \\
\hline & \multirow{3}{*}{ GRG1 } & $\mathrm{SOC}=9.472+0.050 \mathrm{MBN}+2.734 \mathrm{TN}-0.033 \mathrm{SIN}+0.143 \mathrm{SM}+0.011 \mathrm{DOC}$ & $0.999 * * *$ \\
\hline & & $\mathrm{TN}=-0.423+0.171 \mathrm{SOC}-0.055 \mathrm{SM}$ & $0.863 * * *$ \\
\hline & & $\mathrm{SIC}=16.809-2.334 \mathrm{TN}$ & $0.696^{* * *}$ \\
\hline & \multirow{3}{*}{ GRG2 } & $\mathrm{SOC}=1.719+22.265 \mathrm{AWCD}$ & $0.778^{* * *}$ \\
\hline & & $\mathrm{TN}=8.998-0.164 \mathrm{SIC}-0.579 \mathrm{pH}$ & $0.975 * * *$ \\
\hline & & $\mathrm{SIC}=50.209-5.717 \mathrm{TN}-3.068 \mathrm{pH}$ & $0.957 * * *$ \\
\hline & \multirow{3}{*}{ GRG3 } & $\mathrm{SOC}=259.958-30.268 \mathrm{pH}+0.283 \mathrm{BGB}$ & $0.977 * * *$ \\
\hline & & $\mathrm{TN}=26.676-3.077 \mathrm{pH}$ & $0.886^{* * *}$ \\
\hline & & $\mathrm{SIC}=-102.219+14.714 \mathrm{pH}-0.211 \mathrm{SIN}+0.051 \mathrm{BGB}$ & $0.999 * * *$ \\
\hline & \multirow{3}{*}{ NG } & $\mathrm{SOC}=585.446-72.878 \mathrm{pH}$ & $0.932 * * *$ \\
\hline & & $\mathrm{TN}=1.832+5.736 \mathrm{AWCD}-0.191 \mathrm{DON}$ & $0.989 * * *$ \\
\hline & & $\mathrm{SIC}=24.453-4.550 \mathrm{TN}$ & $0.865^{* * *}$ \\
\hline \multirow{14}{*}{$\begin{array}{l}\text { Maqin } \\
\text { County }\end{array}$} & \multirow{2}{*}{ Total } & $\mathrm{SOC}=0.991+10.875 \mathrm{TN}+0.641 \mathrm{BGB}-0.017 \mathrm{DOC}$ & $0.989 * * *$ \\
\hline & & $\mathrm{TN}=0.088 \mathrm{SOC}-0.050 \mathrm{BGB}+0.002 \mathrm{DOC}$ & $0.985 * * *$ \\
\hline & \multirow{3}{*}{ HTT } & $\mathrm{SOC}=-1.569+11.561 \mathrm{TN}$ & $0.988 * * *$ \\
\hline & & $\mathrm{TN}=0.159+0.085 \mathrm{SOC}$ & $0.988 * * *$ \\
\hline & & $\mathrm{SIC}=-0.001+0.120 \mathrm{TN}$ & $0.850 * * *$ \\
\hline & \multirow{3}{*}{ WL } & $\mathrm{SOC}=-1.575+10.980 \mathrm{TN}$ & $0.977 * * *$ \\
\hline & & $\mathrm{TN}=-0.484+0.071 \mathrm{SOC}+1.284 \mathrm{AWCD}$ & $0.991 * * *$ \\
\hline & & $\mathrm{SIC}=8.864-0.252 \mathrm{SOC}$ & $0.836^{* * *}$ \\
\hline & \multirow{3}{*}{ WF } & $\mathrm{SOC}=16.766+1.175 \mathrm{SIN}$ & $0.918 * * *$ \\
\hline & & $\mathrm{TN}=2.900+0.223 \mathrm{BGB}$ & $0.898 * * *$ \\
\hline & & $\mathrm{SIC}=0.828-0.002 \mathrm{MBC}$ & $0.862 * * *$ \\
\hline & \multirow{6}{*}{ Total } & $\mathrm{SOC}=-2.773+9.293 \mathrm{TN}+0.683 \mathrm{BGB}+8.873 \mathrm{AWCD}$ & $0.999 * * *$ \\
\hline & & $\mathrm{TN}=0.296+0.107 \mathrm{SOC}-0.073 \mathrm{BGB}-0.923 \mathrm{AWCD}$ & $0.998 * * *$ \\
\hline & & $\mathrm{SIC}=0.280+0.004 \mathrm{SOC}-0.119 \mathrm{AWCD}$ & $0.936^{* * *}$ \\
\hline \multirow{9}{*}{$\begin{array}{l}\text { Guinan } \\
\text { County }\end{array}$} & & $\mathrm{SOC}=-2.412+9.440 \mathrm{TN}+0.145 \mathrm{BGB}$ & $0.950 * * *$ \\
\hline & & $\mathrm{TN}=0.802+0.086 \mathrm{SOC}$ & $0.926^{* * *}$ \\
\hline & & $\mathrm{SIC}=19.838-0.381 \mathrm{SOC}$ & $0.858 * * *$ \\
\hline & \multirow{3}{*}{ RG } & $\mathrm{SOC}=-2.135+8.093 \mathrm{TN}+0.324 \mathrm{DON}$ & $0.964 * * *$ \\
\hline & & $\mathrm{TN}=0.840+0.084 \mathrm{SOC}$ & $0.939 * * *$ \\
\hline & & $\mathrm{SIC}=25.999-3.807 \mathrm{TN}-10.306 \mathrm{AWCD}+0.004 \mathrm{MBC}$ & $0.921 * * *$ \\
\hline & \multirow{3}{*}{ NG } & $\mathrm{SOC}=-5.529+10.881 \mathrm{TN}$ & $0.944 * * *$ \\
\hline & & $\mathrm{TN}=0.909+0.065 \mathrm{SOC}+0.027 \mathrm{DON}$ & $0.970 * * *$ \\
\hline & & $\mathrm{SIC}=-197.466+26.929 \mathrm{pH}$ & $0.795^{* * *}$ \\
\hline
\end{tabular}


Table 1. Continued.

Note: $\mathrm{NG}=$ natural grazing grassland, $\mathrm{GFG}=$ Grain for Green, GFG1 = grass belt, GFG2 = forest belt, GFG3 = enclosure,

$\mathrm{HTT}=$ extreme degradation-black soil beach, $\mathrm{WL}=$ winter grazing pasture, $\mathrm{WF}=$ year-round forbidden grazing pasture,

$\mathrm{RG}=$ rest-grazing, $\mathrm{SOC}=$ soil organic carbon, $\mathrm{SIC}=$ soil inorganic $\mathrm{C}, \mathrm{TN}=$ soil total nitrogen, $\mathrm{SIN}=$ soil inorganic $\mathrm{N}, \mathrm{MBC}=$ soil microbial biomass $\mathrm{C}, \mathrm{DOC}=$ dissolved organic $\mathrm{C}, \mathrm{MBN}=$ soil microbial biomass $\mathrm{N}, \mathrm{DON}=$ dissolved organic $\mathrm{N}, \mathrm{AWCD}=$ average well color development (microbial metabolic activities based on the use of different $\mathrm{C}$ sources), $\mathrm{pH}=$ soil $\mathrm{pH}$, $\mathrm{BGB}=$ belowground biomass, $\mathrm{SM}=$ soil moisture. Significance of the linear regression was marked with three asterisks $(P<0.001)$.

SICD in 0-30 cm soil layer: Compared with HTT, WL increased $716.22 \%$ and WF increased by $89.19 \%$, 12 years after restoration.

TND in $0-30 \mathrm{~cm}$ soil layer: Compared with HTT, after 12 years of recovery, WL increased by $49.16 \%$ and WF increased by $71.40 \%$.

TCD (SOCD+SICD) in 0-30 cm soil layer: Compared with HTT, WL increased by $47.78 \%$ and WF increased by $77.28 \%$ after 12 years of restoration.

\section{Factors Influencing Soil C and N}

The results of stepwise regression analysis (Table 1) showed that the factors affecting soil $\mathrm{C}$ and $\mathrm{N}$ content were slightly different under different grassland restoration measures in different areas. Generally, in the rest-grazing pasture of Guinan, root biomass, microbial activity and soil $\mathrm{pH}$ are the main factors. In the Tongde area of 'Grain for Green', physical factors (soil moisture, $\mathrm{pH}$ ), biomass factor (root biomass) and microbial activity (e.g., AWCD, MBC, MBN) have significant effects on soil $\mathrm{C}$ and $\mathrm{N}$. In the restored area of artificial grassland in Maqin, root biomass and microbial activity are the main factors affecting soil $\mathrm{C}$ and $\mathrm{N}$ content. On the whole, both biological and abiotic factors have effects on soil C and $\mathrm{N}$ content and density, but the degree of influence varies with geographical location.

\section{Discussion}

\section{Response of Soil C and N Densities to Rest-Grazing}

Through the role of natural forces, rest-grazing can enhance community productivity and improve the vegetation and soil condition of degraded grassland, which is one of the means of restoration and management of degraded grassland [33]. The results showed that long-term rest-grazing (8 years) increased aboveground and underground biomass [34], while short-term grazing increased grassland community height, coverage and biomass [35], as well as soil C, $\mathrm{N}$ and phosphorus contents (rest grazing for one year) also increased in varying degrees [36]. This is similar to our results (Table 2), except for SIC. The relatively high SIC in grazing land may be due to the increased degradation of organic matter caused by grazing disturbance, which increases the partial pressure of $\mathrm{CO}_{2}$ and facilitates the formation of SIC $[30,37]$. The overall impact of grazing rest is to stabilize the grassland ecosystem [35]. Rest-grazing can alleviate the adverse effects of grazing on vegetation, increase vegetation diversity, aboveground and underground biomass, and make the vegetation trampled by cattle and sheep enter the stage of natural restoration [38].

\section{Response of Soil C and N Density to 'Grain for Green'}

Returning farmland to forest/grass is an effective measure to restore soil fertility and improve soil quality. Farmland abandonment and vegetation restoration reduced the tillage pressure on soil. With the growth, development and succession of vegetation, there will be a large number of herbaceous plants, plant roots and surface litter that can increase the content of soil organic matter (SOM), slow down the decomposition of organic matter, and then affect the quality of soil and nutrient changes, which will have positive significance for regional $\mathrm{C}$ emission reduction in the long run [39-40]. Zhao et al. (2015) compared photosynthetic $\mathrm{C}$ fixation between natural grassland and artificial grassland (annual oat and perennial elymus) by the isotope ${ }^{13} \mathrm{C}$ labeling method [41]. We found that natural grassland with high species richness and root/shoot ratio could preserve more $\mathrm{C}$, followed by perennial artificial grassland, and annual artificial grassland (single species) was the least. This is similar to the results of this paper, after farmland conversion, the $\mathrm{C}, \mathrm{N}$ recovery of single planting Elymus nutans (less tillage, trampling disturbance in winter) is slower, while the $\mathrm{C}$ and $\mathrm{N}$ recovery of forest belt (with high species diversity, no tillage, trampling disturbance in winter) is the fastest, followed by GFG3 (no disturbance). The results also show that no-tillage and perennial forage systems (corresponding to NG in this paper) are conducive to the generation of physically stable macroaggregates, thus helping to protect soil organic matter from microbial degradation in different grain sizes [42]. At the same time, a higher organic $\mathrm{C}$ returning system (or lower loss of organic C) and lower soil disturbance are more conducive to the high stability of soil structure [42]. Farming destroys large aggregates and increases the proportion of small aggregates and silt + clay components, which promotes microbial degradation of exposed SOM. This reduces stability and makes the soil more vulnerable to wind or water erosion [43], which accelerates the loss of soil $\mathrm{C}$ and $\mathrm{N}$. There was 


\begin{tabular}{|c|c|c|c|c|c|c|}
\hline : & $\begin{array}{l}\widehat{\approx} \\
\sigma \\
\grave{0} \\
\stackrel{0}{\infty} \\
\infty \\
\stackrel{\sim}{i}\end{array}$ & 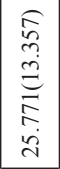 & 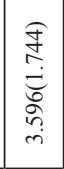 & 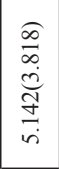 & 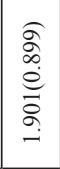 & 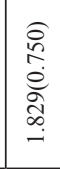 \\
\hline 离 & $\begin{array}{l}\widehat{a} \\
\stackrel{0}{0} \\
\stackrel{0}{0} \\
\stackrel{0}{-}\end{array}$ & $\begin{array}{c}\widehat{\sigma} \\
\stackrel{n}{0} \\
\stackrel{0}{0} \\
o \\
\stackrel{0}{-}\end{array}$ & 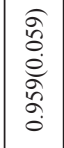 & 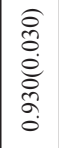 & 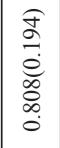 & 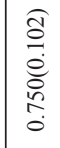 \\
\hline ż & 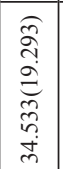 & 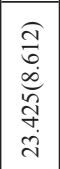 & 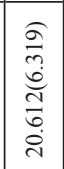 & 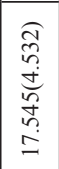 & 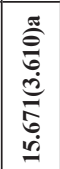 & 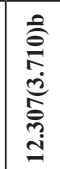 \\
\hline 总 & 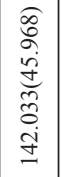 & 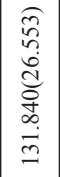 & 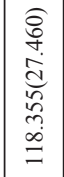 & 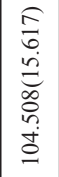 & 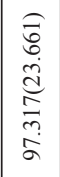 & 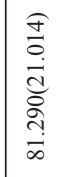 \\
\hline ષ̊ & 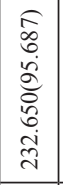 & 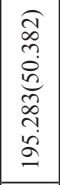 & 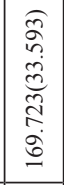 & 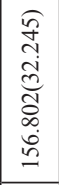 & 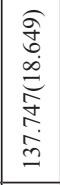 & 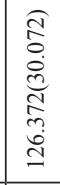 \\
\hline 曾 & 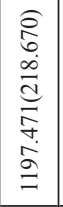 & 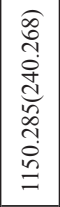 & 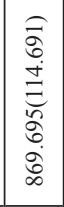 & 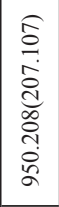 & 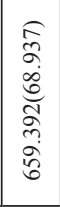 & 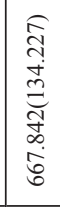 \\
\hline Z & $\begin{array}{l}\widehat{J} \\
\underset{d}{d} \\
\stackrel{d}{d} \\
\stackrel{d}{\circ}\end{array}$ & 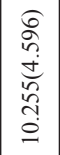 & 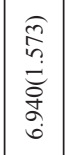 & 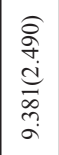 & 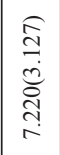 & 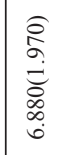 \\
\hline そ & 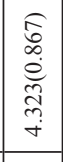 & 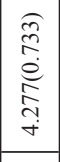 & 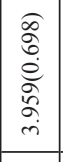 & 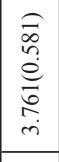 & 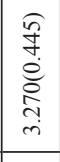 & 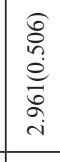 \\
\hline$\frac{u}{n}$ & 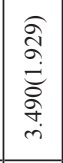 & 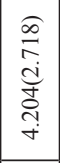 & 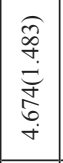 & 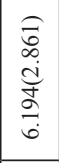 & 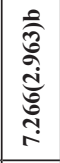 & 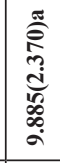 \\
\hline 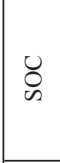 & 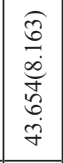 & 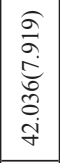 & 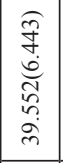 & 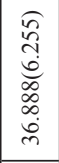 & 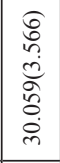 & 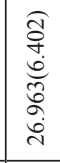 \\
\hline$\sum$ & 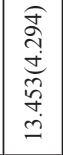 & 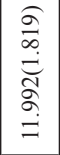 & 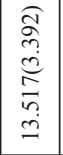 & 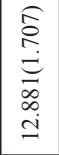 & 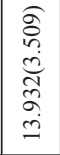 & 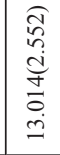 \\
\hline 闹 & \begin{tabular}{l}
$\widehat{I}$ \\
$\stackrel{0}{0}$ \\
0 \\
\multirow{0}{0}{} \\
0
\end{tabular} & 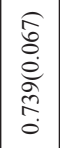 & $\mid \begin{array}{c}\widehat{\widehat{Z}} \\
\stackrel{0}{0} \\
\stackrel{0}{0} \\
0 \\
0\end{array}$ & $\begin{array}{l}\widehat{\widehat{I}} \\
\stackrel{0}{0} \\
\infty \\
\infty \\
\infty \\
0 \\
0\end{array}$ & 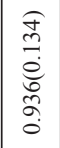 & $\begin{array}{l}1 \\
\hat{2} \\
0 \\
0 \\
0 \\
0 \\
0 \\
0 \\
0 \\
0\end{array}$ \\
\hline 考 & 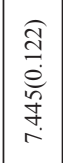 & 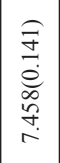 & $\mid \begin{array}{c}\widehat{\delta} \\
\stackrel{\delta}{0} \\
\dot{0} \\
\vdots \\
i \\
i\end{array}$ & 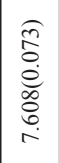 & 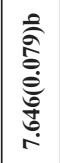 & 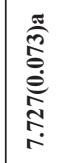 \\
\hline 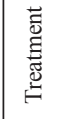 & $\ddot{\varkappa}$ & $\mathfrak{z}$ & $\stackrel{0}{\simeq}$ & $\begin{array}{l}0 \\
z\end{array}$ & $\begin{array}{l}0 \\
\simeq\end{array}$ & Z \\
\hline 哥 & \multicolumn{2}{|c|}{$\frac{0}{3} \bar{z}$} & \multicolumn{2}{|c|}{ 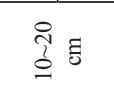 } & \multicolumn{2}{|c|}{ 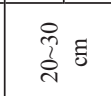 } \\
\hline
\end{tabular}

no significant difference in SOCD and TND between cropland and grass belt. The results were similar to those of Sarker et al. (2018), which may be related to annual fertility input of cultivated land [42]. However, the results were different from those of Li et al. (2016) in the Qinghai Lake area, and the higher SIC in cultivated land in Qinghai Lake area was also different from ours [32]. The SIC of NG was higher than that of cropland. The impact of land use on SIC and SOC is not entirely consistent. After farmland conversion, SOC under GFG3 was relatively high, but there was no significant difference with GFG1 and GFG2. The slowest increase of SIC in GFG3 may be due to the lack of moderate disturbance such as animal trampling, which slows down the decomposition of organic matter and plant roots, thus reducing the source of $\mathrm{CO}_{2}$ that generates SIC, and weakening the transfer of SOC to SIC [44]. Therefore, at the same time of implementing the GFG project, moderate interference is helpful to restore soil fertility.

\section{Response of Soil C and N density to Measures of Artificial Grassland Planting}

For extremely degraded grassland, the quality of which is very poor, its primary vegetation species basically disappeared and evolved into a large area of secondary bare land - "black soil beach" - accompanied by toxic and harmful plants, litter disappeared, the proportion of edible forage decreased to almost zero, soil erosion, organic matter reduced by more than one-fold [1], which is in line with our results (Table 4). For the restoration of this kind of grassland, the measures of artificial community rebuilding were adopted, which included the mixed planting of the upper grass (Elymus nutans) and the lower grass (Poa pratensis) [1], which not only restored the grassland vegetation quickly, but also provided high-quality pasture for grazing livestock [45]. The trampling of livestock increased litter and soil $\mathrm{C}, \mathrm{N}$ input [1] and improved soil quality. Liu et al. (2015) found that SOC decreased and SIC content increased with the degree of degradation [24], which was different from the change of SIC in our results. In our study area, SIC, like SOC, is also the lowest in HTT, which may be related to the lack of litter in HTT and the decrease of soil microbial activity. At the same time, the degree of soil acidification in HTT is more serious [30] (Table 4). The SICD of WL treatment was significantly higher than that of other treatments, even $128.79 \%$ higher than that of NG. This may be due to the change of acidic environment of original soil after 12 years of planting artificial grassland, which is conducive to SIC accumulation [30].

\section{Comparison of Soil C and N Densities in Natural Grassland in Different Areas}

Comparing the $\mathrm{C}$ and $\mathrm{N}$ densities of natural grasslands in three areas, we found that TCD and 


\begin{tabular}{|c|c|c|c|c|c|c|c|c|c|c|c|c|c|c|c|}
\hline 兽 & - & 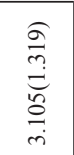 & 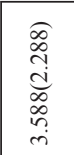 & 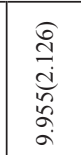 & 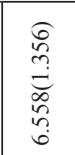 & - & 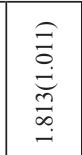 & 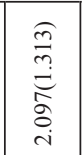 & 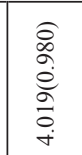 & 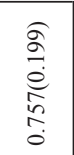 & - & 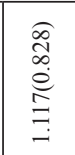 & $\begin{array}{l}\widehat{O} \\
0 \\
0 \\
0 \\
0 \\
0 \\
0 \\
0\end{array}$ & $\begin{array}{l}\text { 秄 } \\
\stackrel{0}{0} \\
\stackrel{0}{\infty} \\
\frac{\infty}{i}\end{array}$ & \\
\hline 害 & 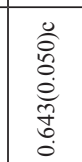 & $\begin{array}{l}\stackrel{0}{\hat{\delta}} \\
\stackrel{0}{0} \\
\stackrel{0}{5} \\
0 \\
\end{array}$ & 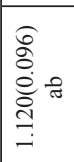 & 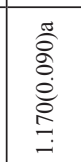 & 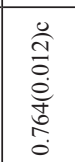 & 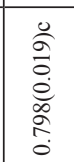 & 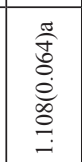 & 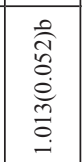 & 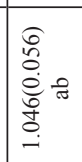 & 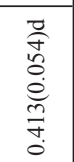 & $\begin{array}{l}\widehat{0} \\
\stackrel{3}{0} \\
0 \\
\infty \\
0 \\
0\end{array}$ & 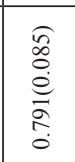 & $\begin{array}{l}0 \\
0 \\
0 \\
0 \\
0 \\
\vdots \\
0 \\
0 \\
0\end{array}$ & $\begin{array}{l}0 \\
0 \\
0 \\
0 \\
0 \\
o \\
o \\
0\end{array}$ & 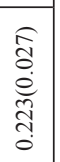 \\
\hline zֵ & 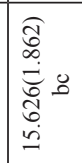 & 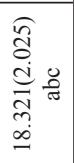 & 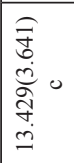 & \begin{tabular}{|l|}
$\infty$ \\
$\tilde{n}$ \\
$\tilde{n}$ \\
$\tilde{\omega}$ \\
$\infty$ \\
$\infty$ \\
$\stackrel{\sim}{\sim}$ \\
$\tilde{n}$
\end{tabular} & 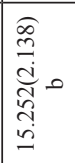 & 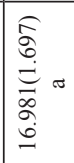 & 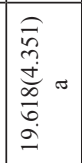 & 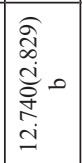 & 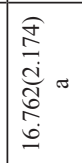 & 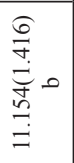 & 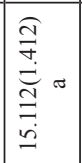 & 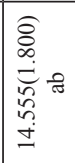 & 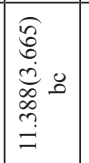 & 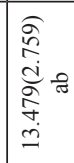 & 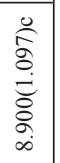 \\
\hline 爰 & 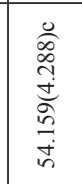 & 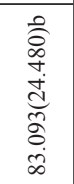 & 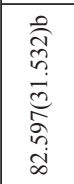 & 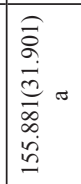 & 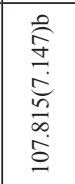 & 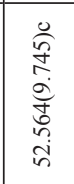 & 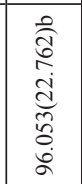 & 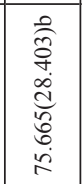 & 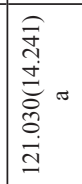 & 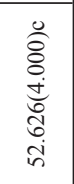 & 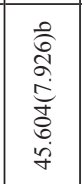 & 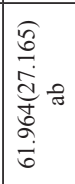 & 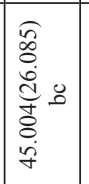 & 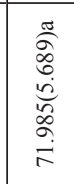 & 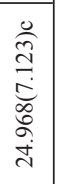 \\
\hline ठ̊ & 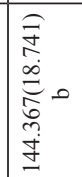 & 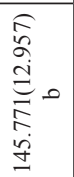 & 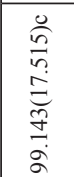 & 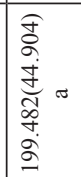 & 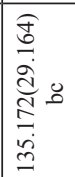 & 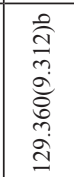 & 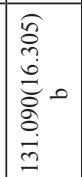 & 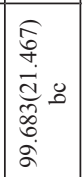 & 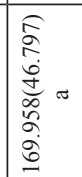 & 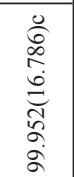 & 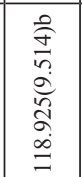 & 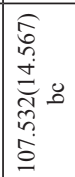 & 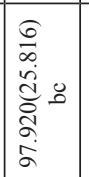 & 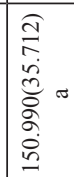 & 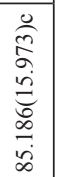 \\
\hline$\stackrel{\mathscr{m}}{z}$ & 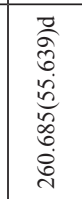 & 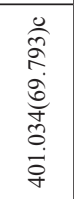 & 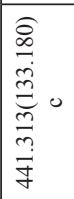 & 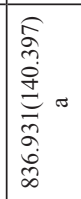 & 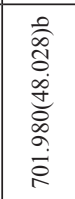 & 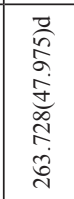 & 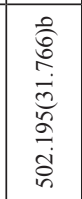 & \begin{tabular}{|c|}
0 \\
0 \\
0 \\
0 \\
0 \\
0 \\
0 \\
0 \\
0 \\
0 \\
0 \\
0
\end{tabular} & 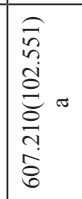 & 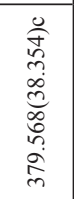 & 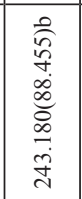 & 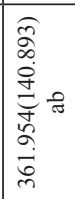 & 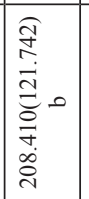 & 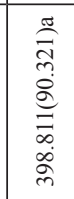 & 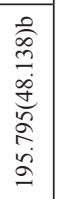 \\
\hline$z$ & 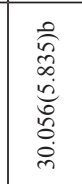 & 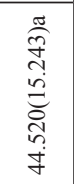 & 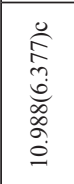 & 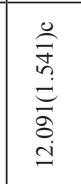 & 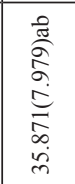 & 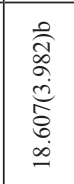 & 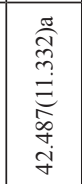 & 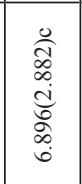 & 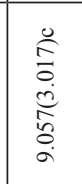 & 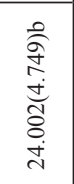 & 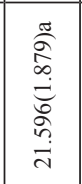 & 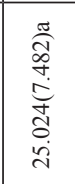 & 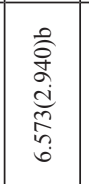 & 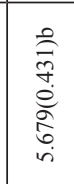 & 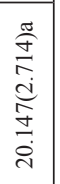 \\
\hline そ & 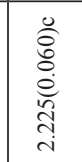 & 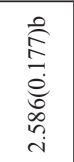 & 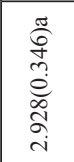 & 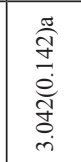 & 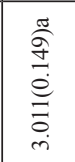 & 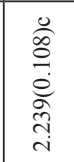 & 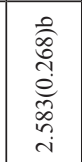 & 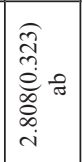 & 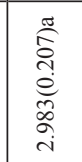 & 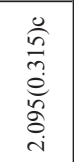 & 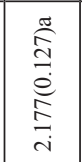 & 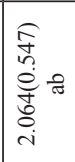 & 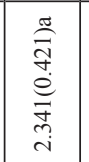 & 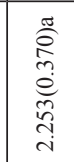 & 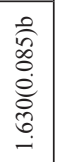 \\
\hline$\stackrel{v}{n}$ & 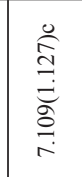 & 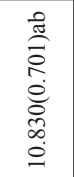 & 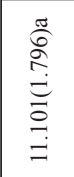 & 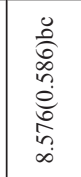 & 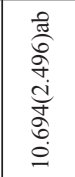 & 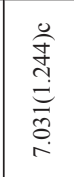 & 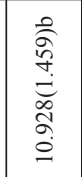 & 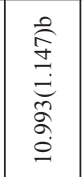 & 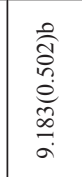 & 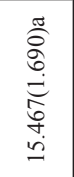 & 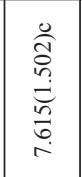 & 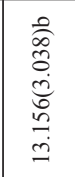 & 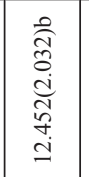 & 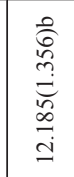 & 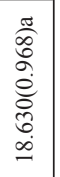 \\
\hline $\mathbb{D}_{n}$ & 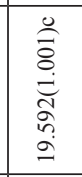 & 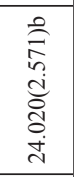 & 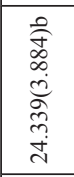 & 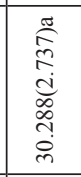 & 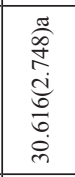 & 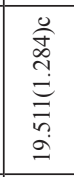 & 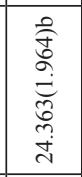 & 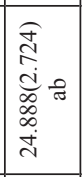 & 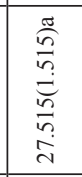 & 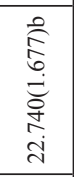 & 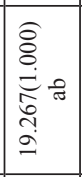 & 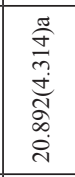 & 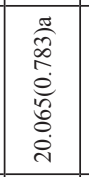 & 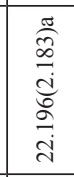 & 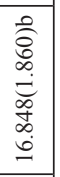 \\
\hline$\sum_{n}$ & 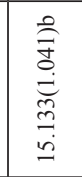 & 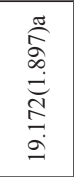 & 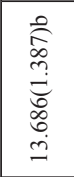 & 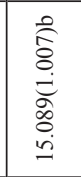 & 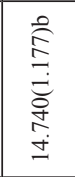 & 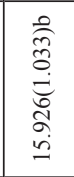 & 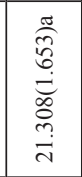 & 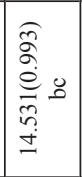 & 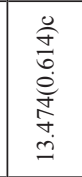 & 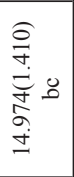 & 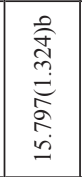 & 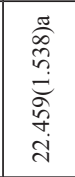 & 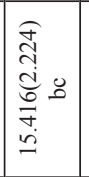 & 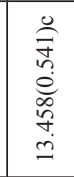 & 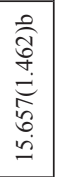 \\
\hline ले & 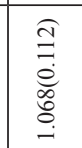 & 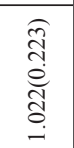 & 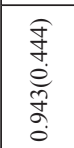 & 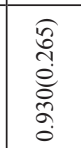 & 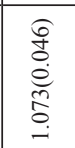 & 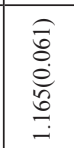 & 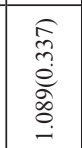 & 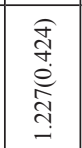 & 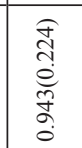 & $\begin{array}{l}\widehat{\widehat{o}} \\
\stackrel{0}{0} \\
\stackrel{0}{0} \\
=\end{array}$ & 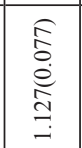 & $\begin{array}{l}\widehat{I} \\
\stackrel{\Xi}{0} \\
\underline{0} \\
0 \\
0 \\
-\end{array}$ & 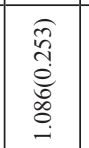 & 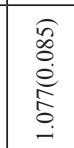 & 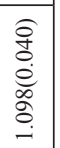 \\
\hline 펼 & 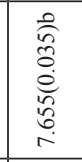 & 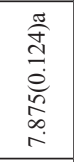 & 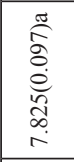 & 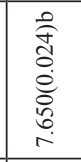 & 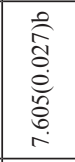 & 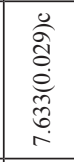 & 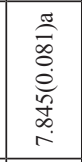 & 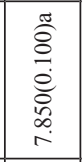 & 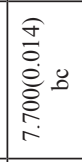 & 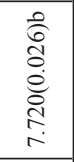 & 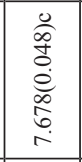 & \begin{tabular}{l}
\multicolumn{0}{c}{} \\
0 \\
0 \\
0 \\
0 \\
0 \\
$\infty$ \\
\end{tabular} & 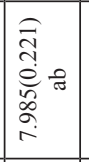 & 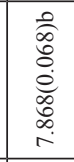 & 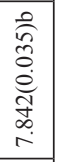 \\
\hline 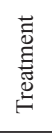 & $\begin{array}{l}\overrightarrow{\widetilde{J}} \\
\frac{\vec{J}}{2} \\
\dot{0}\end{array}$ & $\begin{array}{l}\overrightarrow{0} \\
\text { 岙 }\end{array}$ & $\begin{array}{l}\text { Õ } \\
\text { 岙 }\end{array}$ & $\begin{array}{l}8 \\
\text { S } \\
\text { 要 }\end{array}$ & Z & 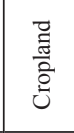 & $\begin{array}{l}\bar{J} \\
\text { 菏 }\end{array}$ & $\begin{array}{l}\text { Õ } \\
\text { 苛 }\end{array}$ & $\begin{array}{l}3 \\
\text { S }\end{array}$ & Z & $\begin{array}{l}\overrightarrow{\widetilde{E}} \\
\frac{\overrightarrow{0}}{0 .} \\
\vec{d}\end{array}$ & $\begin{array}{l}\overrightarrow{0} \\
\text { 苛 }\end{array}$ & $\begin{array}{l}\text { Õ } \\
\text { 兽 }\end{array}$ & S & $\grave{z}$ \\
\hline 䔍 & & & & & & \multicolumn{5}{|c|}{ 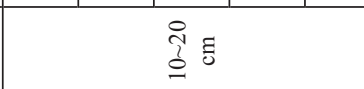 } & \multicolumn{5}{|c|}{ ర్రి } \\
\hline
\end{tabular}




\begin{tabular}{|c|c|c|c|c|c|c|c|c|c|c|c|c|}
\hline 兽 & 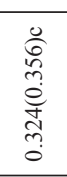 & 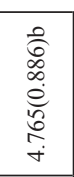 & 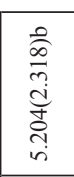 & 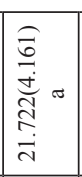 & 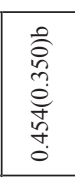 & $\begin{array}{l}0 \\
\stackrel{\infty}{\infty} \\
\infty \\
\infty \\
0 \\
0 \\
\infty \\
\infty \\
0 \\
0\end{array}$ & 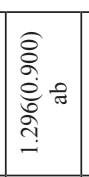 & 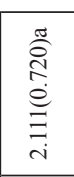 & 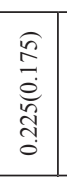 & 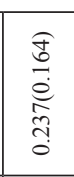 & 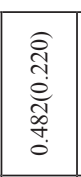 & $\begin{array}{l}\widehat{N} \\
\hat{e} \\
\hat{\Sigma} \\
\hat{\tilde{N}} \\
0\end{array}$ \\
\hline $\begin{array}{l}8 \\
\vdots\end{array}$ & 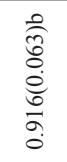 & 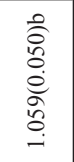 & 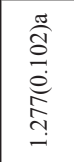 & 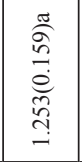 & 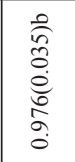 & 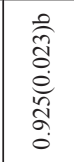 & 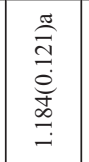 & 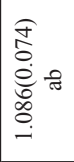 & 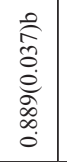 & $\begin{array}{l}\stackrel{0}{0} \\
0 \\
0 \\
0 \\
\infty \\
\infty \\
0 \\
0\end{array}$ & 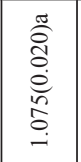 & $\begin{array}{l}0 \\
0 \\
0 \\
0 \\
0 \\
0 \\
\infty \\
\infty \\
0 \\
0 \\
0\end{array}$ \\
\hline ż & 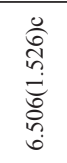 & 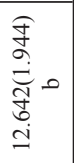 & 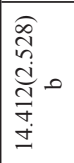 & 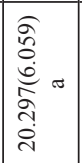 & 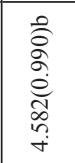 & 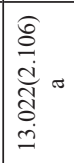 & 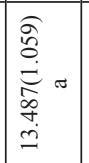 & 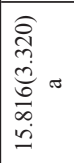 & 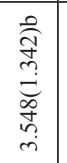 & 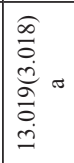 & 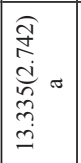 & 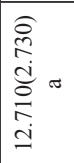 \\
\hline 总 & 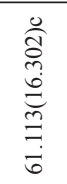 & 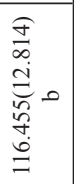 & 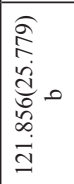 & 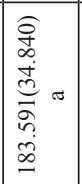 & 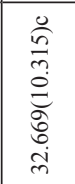 & $\begin{array}{l}\stackrel{0}{0} \\
\infty \\
\stackrel{0}{0} \\
\Xi \\
\vdots \\
0 \\
0\end{array}$ & 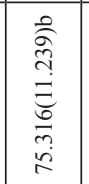 & 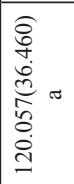 & 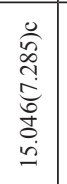 & 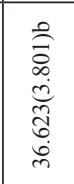 & 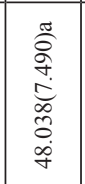 & 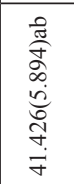 \\
\hline ठ & 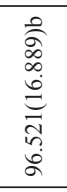 & 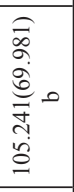 & 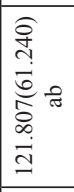 & 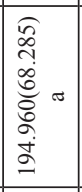 & 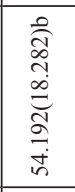 & 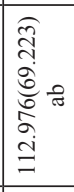 & 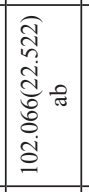 & 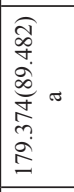 & 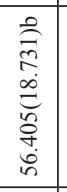 & 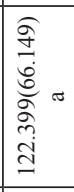 & 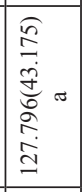 & 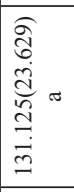 \\
\hline 曾 & 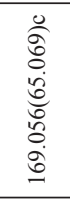 & 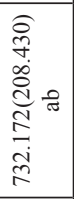 & 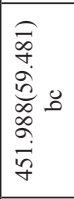 & 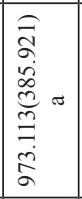 & 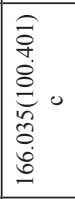 & 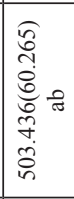 & 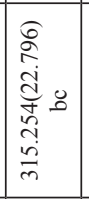 & 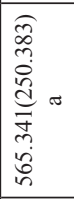 & 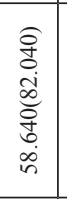 & 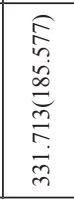 & 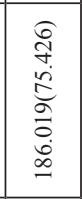 & 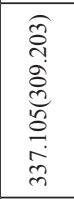 \\
\hline z & 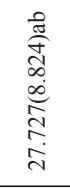 & 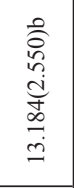 & 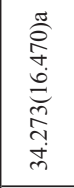 & 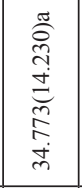 & 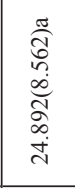 & 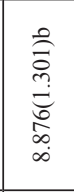 & 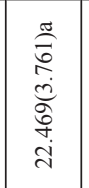 & 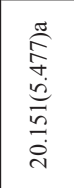 & 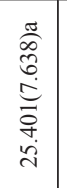 & 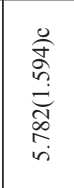 & 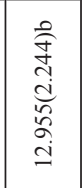 & 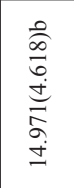 \\
\hline そ & 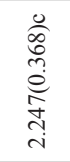 & 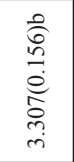 & 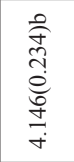 & 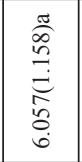 & 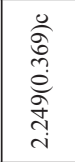 & 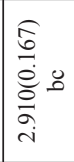 & 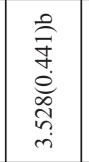 & 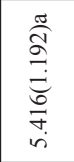 & 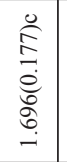 & 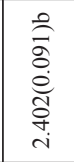 & 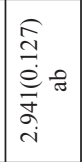 & 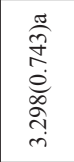 \\
\hline$\ddot{v}$ & $\begin{array}{l}\widehat{\sigma} \\
\stackrel{0}{0} \\
\stackrel{0}{0} \\
\stackrel{0}{0}\end{array}$ & 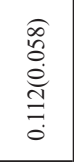 & $\begin{array}{l}\widehat{\delta} \\
\stackrel{0}{0} \\
\stackrel{0}{0} \\
\stackrel{0}{0} \\
\stackrel{0}{0}\end{array}$ & $\begin{array}{l}\widehat{\overrightarrow{0}} \\
\dot{0} \\
\stackrel{+}{0} \\
\stackrel{0}{0}\end{array}$ & 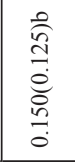 & 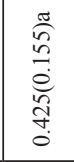 & 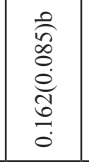 & 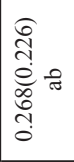 & 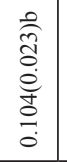 & 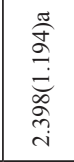 & 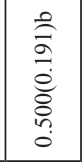 & 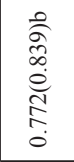 \\
\hline O্ & 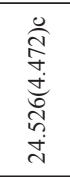 & 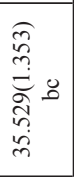 & 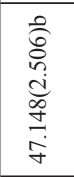 & 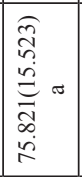 & 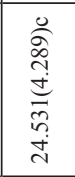 & 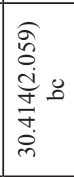 & $\mid$\begin{tabular}{l|}
0 \\
0 \\
0 \\
$\stackrel{0}{d}$ \\
0 \\
$\infty$ \\
0 \\
0 \\
$\dot{+}$
\end{tabular} & 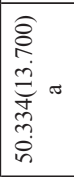 & 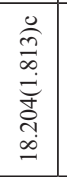 & $\begin{array}{l}\stackrel{0}{0} \\
\infty \\
\infty \\
0 \\
0 \\
0 \\
\stackrel{d}{d} \\
\dot{d}\end{array}$ & 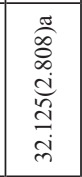 & 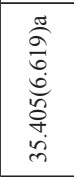 \\
\hline$\sum$ & 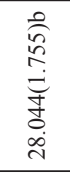 & 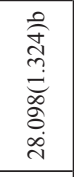 & 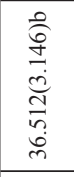 & 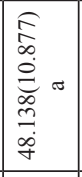 & 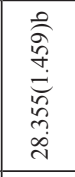 & 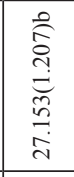 & 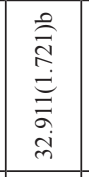 & 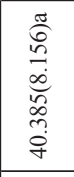 & 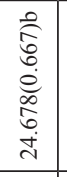 & $\begin{array}{l}\stackrel{0}{0} \\
\infty \\
0 \\
0 \\
0 \\
0 \\
\dot{d} \\
\dot{d}\end{array}$ & 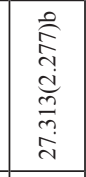 & 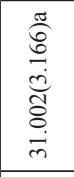 \\
\hline लि & 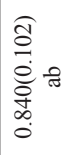 & 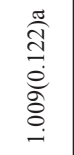 & 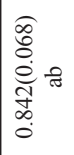 & 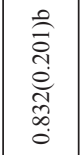 & $\begin{array}{l}\widehat{o} \\
\stackrel{0}{0} \\
\stackrel{0}{0} \\
\stackrel{0}{-1}\end{array}$ & 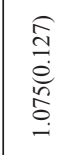 & 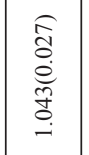 & $\begin{array}{l}\widehat{A} \\
\stackrel{a}{0} \\
\stackrel{0}{0} \\
\stackrel{0}{-}\end{array}$ & 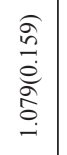 & 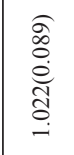 & 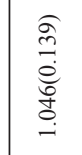 & 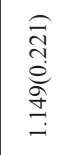 \\
\hline 壱 & $\begin{array}{l}\stackrel{0}{\hat{\sigma}} \\
0 \\
0 \\
\infty \\
\vdots \\
\vdots \\
i\end{array}$ & 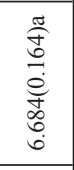 & 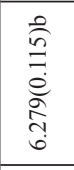 & 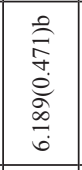 & 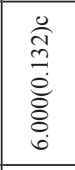 & 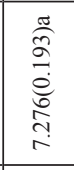 & 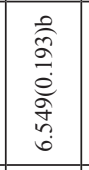 & 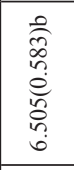 & 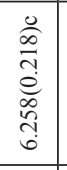 & 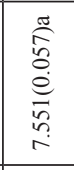 & 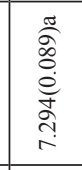 & 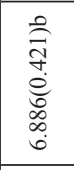 \\
\hline 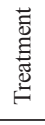 & $E$ & $\xi$ & 3 & $\grave{z}$ & $E$ & $\$$ & $\sum_{3}^{51}$ & $\grave{z}$ & $E$ & $\xi$ & $\sum_{3}^{1}$ & $\stackrel{\mathrm{z}}{ }$ \\
\hline 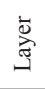 & \multicolumn{4}{|c|}{$\frac{0}{3} \frac{1}{0}$} & \multicolumn{4}{|c|}{ 窎 } & \multicolumn{4}{|c|}{ స్ㅠ: } \\
\hline
\end{tabular}



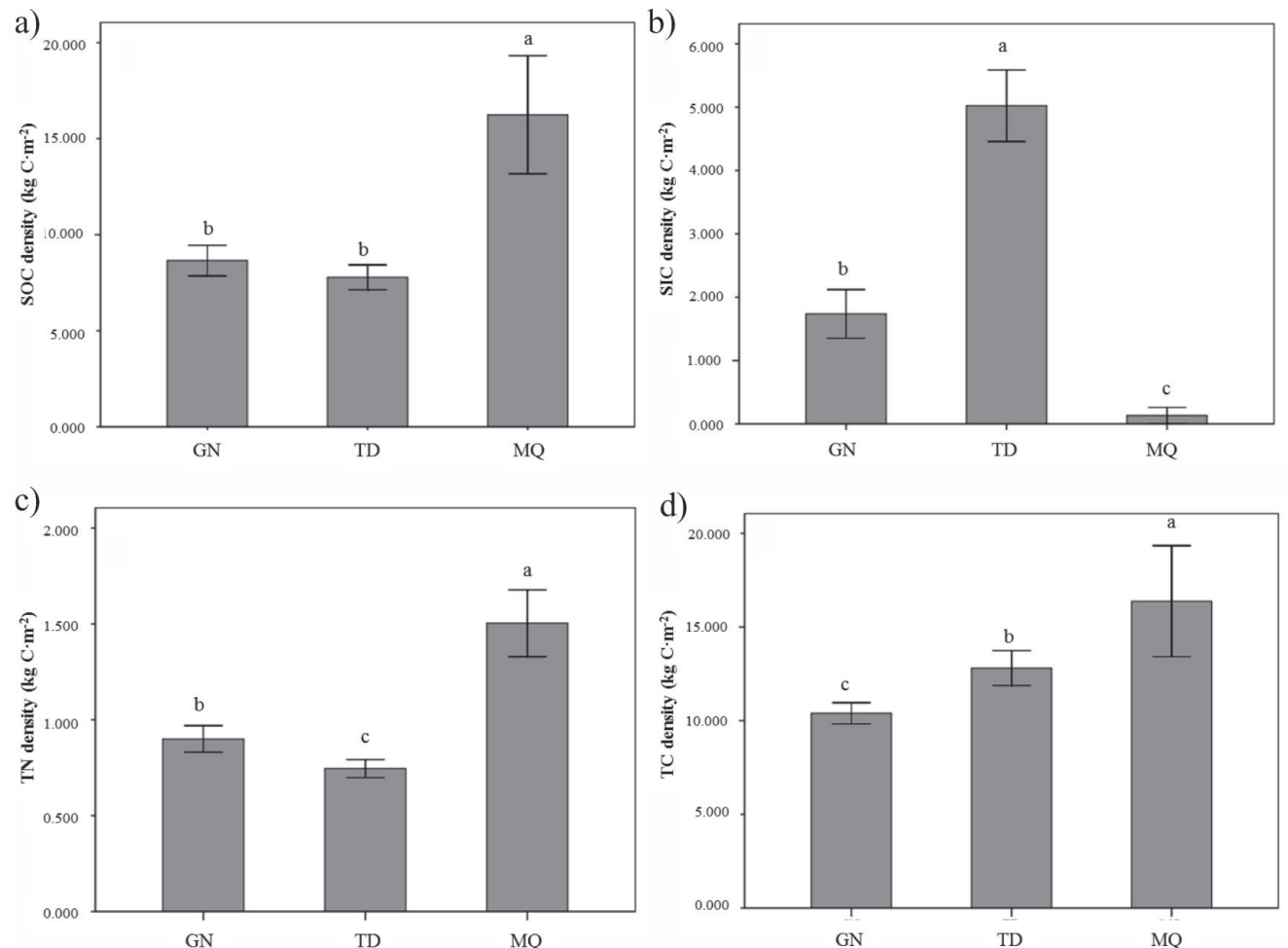

Fig. 4. Surface $(0-30 \mathrm{~cm})$ soil organic carbon density (SOCD, a), soil inorganic carbon density $(\mathrm{SICD}, \mathrm{b})$, total nitrogen density (TND, c) and total carbon density (TCD, d) of normal grazing grassland in GN (Guinan County), TD (Tongde County), and MQ (Maqin County). Different lowercase letters indicate significant differences between different areas at $P<0.05$. Bars indicate mean $\pm \mathrm{SD}$.

SOCD in $0-30 \mathrm{~cm}$ soil of Maqin were significantly higher than those in Guinan and Tongde, while SIC in Tongde was significantly higher than those in Guinan and Maqin. Differences in soil types and climatic zones may be responsible for the differences in soil $\mathrm{C}$ and $\mathrm{N}$ in different regions [42]. 1) The growth of plants in Tongde and Guinan was restricted by relatively low precipitation and high temperature, resulting in a decrease in $\mathrm{C}$ entering the soil system [46-47]. Geographically, the south of Maqin has higher elevation relatively more precipitation and lower temperature, relatively higher productivity and higher $\mathrm{C}$ input to soil [48]. 2) According to the soil characteristics, the soil in Tongde sampling area is dark chestnut calcareous soil with relatively high inorganic C content and strong lime reaction [27, 49], and the soil in the Maqin area is alpine meadow soil with no lime reaction or lime reaction under A/B layer, which is rich in $\mathrm{OM}$ and humus. The soil of Guinan sampling area is carbonate alpine meadow soil, and the content of $\mathrm{OM}$ and humus is slightly lower than that of alpine meadow soil, which has a certain calcification process [50-51].

\section{Conclusions}

Short-term grazing rest in the Sanjiangyuan area has a certain effect on soil fertility restoration. The implementation of the "Grain for Green" project in the agro-pastoral ecotone improves soil fertility. Concurrently, moderate disturbance should be carried out on the basis of increasing vegetation diversity. Artificial grassland planting on black soil beach can improve soil quality, and moderate grazing disturbance in winter had the best immobilization effect on SIC, while no disturbance in the whole year was beneficial to the accumulation of organic matter. Both biological and abiotic factors have effects on soil $\mathrm{C}$ and $\mathrm{N}$ content and density, but the degree of influence varies with geographical location.

\section{Acknowledgements}

This study was supported by the National Key Research and Development Project of China (2016YFC0501805, 2016YFC0501905), “The Dawn of West China" 2018 Talent Training Program of the Chinese Academy of Sciences by Chen Dongdong, the Natural Science Foundation of Qinghai Province (2017-ZJ-939Q), the Special Fund for Strategic Pilot Technology of Chinese Academy of Sciences (XDA23060604), the Young Scientists Fund of the National Natural Science Foundation of China (31700394), and the Key Research and Transformation Project of Qinghai Province (2019-SF-153). We thank Xinchuan Wang from Qinghai Provincial Forage Seed Breeding Farm and other colleagues for field study. We also acknowledge the editor and anonymous 
reviewers for their helpful comments on an earlier draft of this manuscript.

\section{Conflict of Interest}

The authors declare no conflict of interest.

\section{References}

1. ZHAO X.Q. Restoration and Sustainable Management of Degraded Grassland Ecosystem in the Sanjiangyuan Region. Science Press: Beijing, China. 2011.

2. CHEN J., SUN B.M., CHEN D., WU X., GUO L.Z., WANG G. Land Use Changes and Their Effects on the Value of Ecosystem Services in the Small Sanjiang Plain in China. Scientific World Journal. 752846, 2014.

3. XU Q., LI Q., CHEN D.D., LUO C.Y., ZHAO X.Q., ZHAO L. Land use change in the Three-River Headwaters in Recent 40 Years. Arid Zone Research. 35( 03), 695, 2018.

4. LI L.Q. Effect of rest-grazing on the upper reaches of Datong River alpine grassland vegetation. Qinghai University, Qinghai, China. 2018.

5. HUANG C.Y. Soil Science (Edition 1). China Agriculture Press: Beijing, China. 2000.

6. JIAO K.Q., DUAN J.J., WANG X.L., YI X., CHEN Z.Y., BU T.D. Analysis of soil carbon and nitrogen content and storage under different land use patterns. Journal of Mountain Agriculture and Biology. 37 (01), 17, 2018.

7. WANG Y., JIANG J., NIU Z., LI Y., LI C., FENG W. Responses of soil organic and inorganic carbon vary at different soil depths after long-term agricultural cultivation in Northwest China. Land Degradation \& Development. 30 (10), 1229, 2019.

8. OU Y., WANG X., LI J., JIA H., ZHAO Y., HUANG Z., HONG M. Content and ecological stoichiometry characteristics of soil carbon,nitrogen, and phosphorus in artificial grassland under different restoration years. Chinese Journal of Applied and Environmental Biology. 25 (1), 38, 2019.

9. WHISLER K.M., ROWE H.I., DUKES J.S. Relationships among land use, soil texture, species richness, and soil carbon in Midwestern tallgrass prairie, CRP and crop lands. Agriculture Ecosystems \& Environment. 216, 237, 2016.

10. ZHANG L., WANG Y., SHU M., ZHANG Y., LI Z., GUO H., LI C., HU S. Effects of burning on soil net nitrogen mineralization rate and net nitrification rate in a semiarid grassland on the Loess Plateau. Journal of Nanjing Agricultural University. 40 (6), 1051, 2017.

11. MANNING G.C., BAER S.G., BLAIR J.M. Effects of Grazing and Fire Frequency on Floristic Quality and its Relationship to Indicators of Soil Quality in Tallgrass Prairie. Environmental Management. 60 (6), 1062, 2017.

12. LI H.Q., ZHANG F.W., MAO S.J., ZHU J.B., YANG Y.S., HE H.D., LI Y.N. Effects of grazing on soil properties in Maqin Alpine Meadow, Tibetan Plateau, China. Polish Journal of Environmental Studies. 25 (4), 1583, 2016.

13. SHI P., DUAN J., ZHANG Y., LI P., WANG X., LI Z., XIAO L., XU G., LU K., CHENG S., REN Z., ZHANG Y., YANG W. The effects of ecological construction and topography on soil organic carbon and total nitrogen in the
Loess Plateau of China. Environmental Earth Sciences. 78 (5), 2019.

14. TUO D., GAO G., CHANG R., LI Z., MA Y., WANG S., WANG C., FU B. Effects of revegetation and precipitation gradient on soil carbon and nitrogen variations in deep profiles on the Loess Plateau of China. Science of the Total Environment. 626, 399, 2018.

15. ZHOU Y., MA H., JIA X., ZHANG R., SU T., ZHOU J., WU X. Effects of different restoration measures on storage of soil organic carbon and nitrogen in typical steppe of the Loess Hilly Area in Ningxia. Acta Prataculturae Sinica. 26 (12), 236, 2017.

16. ZHONG B., SUN G., CHEN D., ZHANG N. Effects of Different Restoration Measures on Soil Microbial Biomass Carbon and Nitrogen and Soil Enzymes in the Process of Restoration of the Desertified Grassland in Zoige. Ecology and Environmental Sciences. 26 (3), 392, 2017.

17. ZENG Q., LIU Y., XIAO L., HUANG Y. How Fencing Affects the Soil Quality and Plant Biomass in the Grassland of the Loess Plateau. International Journal of Environmental Research and Public Health. 14 (10), 1117, 2017.

18. LI L., HE H., WEI Y., YANG Y., LUO J., LI H., LI Y., ZHOU H. Response of vegetation community structure,soil carbon sequestration, and water-holding capacity in returning farmland to grassland plots, in the agro-pastoral transitional zone in the Three Rivers Source Region. Pratacultural Science. 34 (10), 1999, 2017.

19. WANG Z.Q., DU L.L., ZHAO M., GUO S.L. Differences in soil organic carbon and total nitrogen and their impact factors under different restoration patterns in the Loess Plateau. The Journal of Applied Ecology. 27 (3), 716, 2016.

20. YAHDJIAN L., TOGNETTI P.M., CHANETON E.J. Plant functional composition affects soil processes in novel successional grasslands. Functional Ecology. 31 (9), 1813, 2017.

21. ZUO X., ZHOU X., LV P., ZHAO X., ZHANG J., WANG S., YUE X. Testing Associations of Plant Functional Diversity with Carbon and Nitrogen Storage along a Restoration Gradient of Sandy Grassland. Frontiers in Plant Science. 7, 189, 2016.

22. ZENG Q., LI X., DONG Y., AN S., DARBOUX F. Soil and plant components ecological stoichiometry in four steppe communities in the Loess Plateau of China. Catena. 147, 481, 2016.

23. DU Y.G., GUO X.W., ZHOU G., CAO G.M., LI Y.K. Effects of grazing intensiy on soil and plant $\delta^{15} \mathrm{~N}$ of an Alpine Meadow. Polish Journal of Environmental Studies. 26 (3), 1071, 2017.

24. LIU Y.H., WEI W.D., WEN X.C., LI J.L. Distribution Characteristics of Soil Carbon on Different Degraded Degree Alpine Meadow in the Source Area of Three Major Rivers in China. Hubei Agricultural Sciences. 54 (02), 308, 2015.

25. CHEN D.D., ZHAO L., LI Q., CAI H., LI J.M., XU S.X., ZHAO X.Q. Response of soil carbon and nitrogen to 15-year experimental warming in two alpne habitats (Kobresia meadow and Potentilla shrubland) on the Qinghai-Tibetan Plateau. Polish Journal of Environmental Studies. 26 (6), 2315, 2016.

26. LIU J.J. Analysis and Countermeasures on Desertified Land and Sandified Land in Guinan County of Qinghai Province. Forest Resources Management. 2, 12, 2017. 
27. HOU Y.P., LI Y.X. Analysis of Climate Change Characteristics in Guinan County - 1957-2016. Agriculture and Technology. 39 (10), 137, 2019.

28. LIU J.F., WANG X.C., LIU W.H. Production Performence Evaluation of Four Materials of Elymus in Tongde Region. Chinese Journal of Grassland. 32 (06), 81, 2010

29. SUN M.D., LI Y.H. Breeding and domesticating Tongde Elymus breviaristatus cv. Tongde. Qinghai Prataculture. 17 (04), 2, 2008

30. LIU Z., CHEN D.D., LI Q., ZHAO L., XU S.X., ZHAO $X . Q$. Effects of different land use patterns onsoil inorganic carbon in alpine meadow ecosystems. Bulletin of Soil and Water Conservation. 36 (05), 73, 2016.

31. BAO S.D. Soil Agricultural Chemistry Analysis (Edition 3). China Agriculture Press: Beijing, China. 2000.

32. LI C.L., LI Q., ZHAO L., GE S.D., CHEN D.D., DONG Q.M., ZHAO X.Q. Land-use effects on organic and inorganic carbon patterns in the topsoil around Qinghai Lake basin, Qinghai-Tibetan Plateau. Catena. 147, 345, 2016.

33. YANG J., CHU P.F., CHEN D.M., WANG M.J., BAY Y.F. Mechanisms underlying the impacts of grazing on plant $\alpha$, $\beta$ and $\gamma$ diversity in a typical steppe of the Inner Mongolia grassland. Chinese Journal of Plant Ecology. 38 (02), 188, 2014.

34. NIE C., NIU L., ZHANG X.B., LI Y., DU W., LIU Y.H. Effects of grazing on soil respiration in typical steppe during growing season in Inner Mongolia. Journal of Plant Nutrition and Fertilizers. 25 (03), 402, 2019.

35. XU S.H., CHEN Y.H. Effect of stop grazing on characteristics of plant community and soil nutrients of typical grassland in Xilinguole. Research of Soil and Water Conservation. 25 (04), 15, 2018.

36. WU Y.Q., TIAN Y., ZHOU J.Q., ZHANG K.B. Ecological stoichiometric characteristics of soil carbon, nitrogen and phosphorus in the different grazing regimes. Chinese Journal of Appllied \& Environmental Biology. 1-7, 2018.

37. ZAMANIAN K., PUSTOVOYTOV K., KUZYAKOV Y. Pedogenic carbonates: Forms and formation processes. Earth-Science Reviews. 157, 1, 2016.

38. LIU Z.G., LI Z.Q. Plant biodiversity of Aretemisia frigida communities on degraded grasslands under different grazing intensities after thirteen-year enclosure. Acta Ecologica Sinica. 26 (02), 475, 2006.

39. GONG J., CHEN L.D., FU B.J., LI Y.M., HUANG Z.L., HUANG Y.L. PENG H.J. Effects of land use and vegetation restoration on soil quality in a small catchment of the Loess Plateau. Chinese Journal of Applied Ecology. 15 (12), 2292, 2004.

40. GUO Y.J, HAN J.G. Effects of Returning Cultivated land to Grassland on Soil Chemical Properties in the
Agro-pastoral Transitional Zone of Northern China. Acta Agrestia Sinica. 16 (04), 386, 2008.

41. ZHAO L., CHEN D.D., ZHAO N., LI Q., CHENG Q., LUO C.Y., XU S.X., WANG S.P., ZHAO X.Q. Responses of carbon transfer, partitioning, and residence time to 1 and use in the plant-soil system of an alpine meadow on the Qinghai-Tibetan Plateau. Biology and Fertility of Soils. 51 (7), 781, 2015.

42. SARKER J.R., SINGH B.P., COWIE A.L., FANG Y., COLLINS D., BADGERY W., DALAL R.C. Agricultural management practices impacted carbon and nutrient concentrations in soil aggregates, with minimal influence on aggregate stability and total carbon and nutrient stocks in contrasting soils. Soil \& Tillage Research. 178, 209, 2018.

43. SIX J., ELLIOTT E.T., PAUSTIAN K. Soil macroaggregate turnover and microaggregate formation: a mechanism for $\mathrm{C}$ sequestration under no-tillage agriculture. Soil Biology \& Biochemistry. 32 (14), 2099, 2000.

44. ZHANG Y., ZHANG L., WU W.L., MENG F.Q. Impact of Land Use and Fertilization Measures on Soil C Stock in Farminggrazing Interlacing Zone of Inner Mongolia, China. Acta Pedologica Sinica. 53 (04), 930, 2016.

45. MA Y.S., LANG B.N., LI Q.Y., SHI J.J., DONG Q.M. Study on rehabilitating and rebuilding technologies for degenerated alpine meadow in the Changjiang and Yellow river source region. Pratacultural Science. 19 (09), 1-5, 2002.

46. HOYLE F.C., MURPHY D.V. Seasonal changes in microbial function and diversity associated with stubble retention versus burning. Australian Journal of Soil Research. 44 (4), 407, 2006.

47. SARKER J.R., SINGH B.P., HE X., FANG Y., LI G.D., COLLINS D., COWIE A.L. Tillage and nitrogen fertilization enhanced belowground carbon allocation and plant nitrogen uptake in a semi-arid canola crop-soil system. Scientific Reports. 7, 10726, 2017.

48. DALAL R.C., ALLEN D.E., WANG W.J., REEVES S., GIBSON I. Organic carbon and total nitrogen stocks in a Vertisol following 40 years of no-tillage, crop residue retention and nitrogen fertilisation. Soil \& Tillage Research. 112 (2), 133, 2011.

49. A H.N., A J.J., YANG J.X., TIAN Z.C. A Brief Analysis of Agricultural Soil Fertility in Tongde. Science and Technology of Qinghai Agriculture and Forestry. 1, 18, 1998.

50. LA Y.L. Basic Characteristics of Grassland Types in Guinan County. Prataculture \& Animal Husbandry. 11, 34, 2006.

51. ZHAO X.Q. Alpine meadow ecosystem and global change (Edition 1). Science Press: Beijing, China. 31-32, 2009. 
